\title{
Structure Refinement of the Semiconducting Compound $\mathrm{Cu}_{3} \mathrm{TaS}_{4}$ from X-Ray Powder Diffraction Data*
}

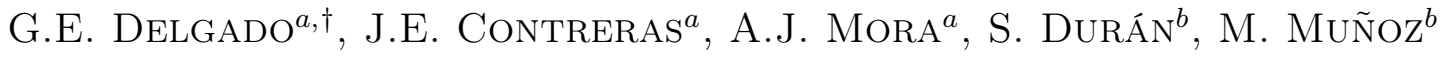 \\ AND P. GRIMA-GALlardo ${ }^{b}$ \\ ${ }^{a}$ Laboratorio de Cristalografía, Departamento de Química, Facultad de Ciencias, Universidad de Los Andes \\ Mérida 5101, Venezuela \\ ${ }^{b}$ Centro de Estudios de Semiconductores, Departamento de Física, Facultad de Ciencias, Universidad de Los Andes \\ Mérida 5101, Venezuela
}

(Received October 5, 2010; in final form April 1, 2011)

\begin{abstract}
The ternary compound $\mathrm{Cu}_{3} \mathrm{TaS}_{4}$ has been investigated by means of X-ray powder diffraction and its structure has been refined by the Rietveld method. This compound is isostructural with the sulvanite mineral $\mathrm{Cu}_{3} \mathrm{VS}_{4}$, and crystallizes in the cubic $P \overline{4} 3 m$ space group (No. 215), $Z=1$, with unit cell parameters $a=5.5145(1) \AA$ and $V=167.70(1) \AA^{3}$. The refinement of 14 instrumental and structural parameters converged to $R_{\mathrm{p}}=4.4 \%$, $R_{\mathrm{wp}}=6.8 \%, R_{\exp }=5.5 \%$ and $S=1.2$ for 4501 step intensities and 33 independent reflections.
\end{abstract}

PACS: $61.50 . \mathrm{Nw}, 61.66 . \mathrm{Fn}$

\section{Introduction}

Ternary compounds belonging to the family $\mathrm{Cu}_{3}-\mathrm{M}-$ $\mathrm{VI}_{4}(\mathrm{M}=\mathrm{V}, \mathrm{Nb}, \mathrm{Ta}, \mathrm{VI}=\mathrm{S}, \mathrm{Se}, \mathrm{Te})$ are interesting materials due principally to their potential applications as electronic devices, especially as light-modulators $[1,2]$. Earlier studies on the lattice vibration in the sulfide and selenide compounds revealed that they belong to the $p$-type semiconductors [3-5]. More recently, the calculated electronic structure of the sulvanite compounds $\mathrm{Cu}_{3} \mathrm{TMS}_{4}(\mathrm{TM}=\mathrm{V}, \mathrm{Nb}, \mathrm{Ta})$, indicated that they are semiconductors with indirect band gap and the analysis of the electron localization function (ELF) reveals the ionic character of these semiconductors materials [6]. Another work shows that the $\mathrm{Cu}_{3} \mathrm{TaS}_{4}-\mathrm{Cu}_{3} \mathrm{TaSe}_{4}$ system exhibits excellent optoelectronic properties as $p$-type conductivity, large optical band gap energy, and tunable visible photoemission [7]. The optical band gap energy of the sulfide $\left(E_{\mathrm{g}}=2.70 \mathrm{eV}\right)$ make $\mathrm{Cu}_{3} \mathrm{TaS}_{4}$ transparent to most visible light, and thin films of this material could be used in transparent electronics as $p$-type layers in active devices including $p-n$ junctions, transistor channel layers, and photovoltaics [7].

From the crystallographic point of view, several authors have reported the preparation of this type of ma-

\footnotetext{
* This is a modified and extended version of a paper presented at VI Congress of the Venezuelan Physical Society in March 2008.

${ }^{\dagger}$ corresponding author; e-mail: gerzon@ula.ve
}

terials and have associated their structures with that of the mineral sulvanite, which crystallizes with cubic symmetry $P \overline{4} 3 m[8,9]$, and therefore are expected to show isotropic electrical and optical properties. The crystal structures of $\mathrm{Cu}_{3} \mathrm{VS}_{4}$ [9], $\mathrm{Cu}_{3} \mathrm{NbS}_{4}$ [10], $\mathrm{Cu}_{3} \mathrm{VSe}_{4}$ [11], $\mathrm{Cu}_{3} \mathrm{NbSe}_{4}$ [12], $\mathrm{Cu}_{3} \mathrm{TaSe}_{4}$ [13], $\mathrm{Cu}_{3} \mathrm{NbTe}_{4}$ [14] and $\mathrm{Cu}_{3} \mathrm{TaTe}_{4}[15]$ have been previously established by means of X-ray diffractometry. For $\mathrm{Cu}_{3} \mathrm{VTe}_{4}$ there is no structural data. In contrast, for $\mathrm{Cu}_{3} \mathrm{TaS}_{4}$ only an early study, using X-ray cameras, was found in the ICSD database [16]. The report, without a crystal structure characterization or $R$ value given in the paper, describes this material as an undistorted sulvanite structure (ICSD \#53335) [16]. In this work, we report the structure of the ternary compound $\mathrm{Cu}_{3} \mathrm{TaS}_{4}$ determined from X-ray powder diffraction data using the Rietveld refinement. Structural analyses of the completed $\mathrm{Cu}_{3}-\mathrm{M}-\mathrm{VI}_{4}(\mathrm{M}=\mathrm{V}, \mathrm{Nb}$, $\mathrm{Ta}, \mathrm{VI}=\mathrm{S}, \mathrm{Se}, \mathrm{Te}$ ) system are also presented.

\section{Experimental}

The sample was synthesized using the melt and annealing technique. Stoichiometric quantities of $\mathrm{Cu}, \mathrm{Ta}$ and $\mathrm{S}$ elements with purity of $99.9 \%$ were charged in an evacuated quartz ampoule, which was previously subjected to pyrolysis in order to avoid reaction of the starting materials with quartz. Then, the ampoule was sealed under vacuum and the fusion process was carried out inside a furnace (vertical position) heated up to $1500^{\circ} \mathrm{C}$ at a rate of $20^{\circ} \mathrm{C} / \mathrm{h}$, with a stop of $48 \mathrm{~h}$ at $150^{\circ} \mathrm{C}$ (melting temperature of S). The ampoule was shaked using a mechanical system during all the heating process in order to guarantee the complete mixing of all the elements. Then, the 
temperature was gradually raised at the same rate up to $850^{\circ} \mathrm{C}$. The ampoule was kept at this temperature for a period of 30 days. Finally, the sample was cooled to room temperature at a rate of $10^{\circ} \mathrm{C} / \mathrm{h}$.

Chemical composition of the ingots was determined at several points by energy dispersive X-ray (EDX) analysis using a Kevex Model Delta-3 system connected to a Hitachi Model S-2500 scanning electron microscope (SEM). The average chemical composition of the central part of the ingot, from which the crystals were cut, gave the atomic percentage of $\mathrm{Cu}(37.4 \%)$, Ta $(12.2 \%)$ and $\mathrm{S}$ $(50.4 \%)$, close to the ideal value $3: 0.98: 4.04$. The error in standardless analysis was around $5 \%$.

For the X-ray analysis, a small quantity of the ingot obtained previously, was ground mechanically in an agate mortar and pestle. The resulting fine powder was mounted on a zero-background holder covered with a thin layer of petroleum jelly. The X-ray powder diffraction data were collected at 298(1) $\mathrm{K}$, in a Philips PW-1250 diffractometer equipped with an X-ray tube $\left(\mathrm{Cu} K_{\alpha}\right.$ radiation: $\lambda=1.54056 \AA ; 40 \mathrm{kV}, 25 \mathrm{~mA}$ ), a diffracted beam graphite monochromator and a scintillation detector. The specimen was scanned from $10-100^{\circ}(2 \theta)$, in steps of $0.02^{\circ}$ and counting time of $50 \mathrm{~s} / \mathrm{step}$. Silicon was used as an external standard.

\section{Results and discussion}

The X-ray diffractogram of $\mathrm{Cu}_{3} \mathrm{TaS}_{4}$ shows a single phase. The measured reflections were completely indexed in a cubic cell by using the program Dicvol04 [17]. As expected, this material is isostructural with the mineral sulvanite $\mathrm{Cu}_{3} \mathrm{VS}_{4}$, which crystallizes in the space group $P \overline{4} 3 m$ (No. 215). The entire powder diffraction dataset of $\mathrm{Cu}_{3} \mathrm{TaS}_{4}$ was reviewed by means of the NBS*AIDS program [18] with the following results: $a=5.5149(1) \AA$, $V=167.73(1) \AA^{3}$, and figures of merit $M_{20}=340.6$ [19] and $F_{26}=190.3(0.0053,26)[20]$. X-ray powder diffraction data of $\mathrm{Cu}_{3} \mathrm{TaS}_{4}$ are given in Table I.

The Rietveld refinement [21] of the $\mathrm{Cu}_{3} \mathrm{TaS}_{4}$ structure was carried out using the Fullprof program [22]. Initial positional parameters were taken from those of $\mathrm{Cu}_{3} \mathrm{TaSe}_{4}$ [13] and unit cell parameters were those yielded by the NBS*AIDS. The angular dependence of the peak full width at half maximum (FWHM) was described by Caglioti's formula. Peak shapes were described by the pseudo-Voigt profile function. The background variation was described by a polynomial with six coefficients. The thermal motion of the atoms was described by one overall isotropic temperature factor. The final figures of merit obtained when 14 above-listed instrumental and structural variables were refined, are summarized in Table II. The final Rietveld plot is shown in Fig. 1. Figure 2 shows the unit cell diagram of $\mathrm{Cu}_{3} \mathrm{TaS}_{4}$. Unit cell parameters, atomic coordinates, isotropic temperature factor, bond distances and angles are shown in Table III.

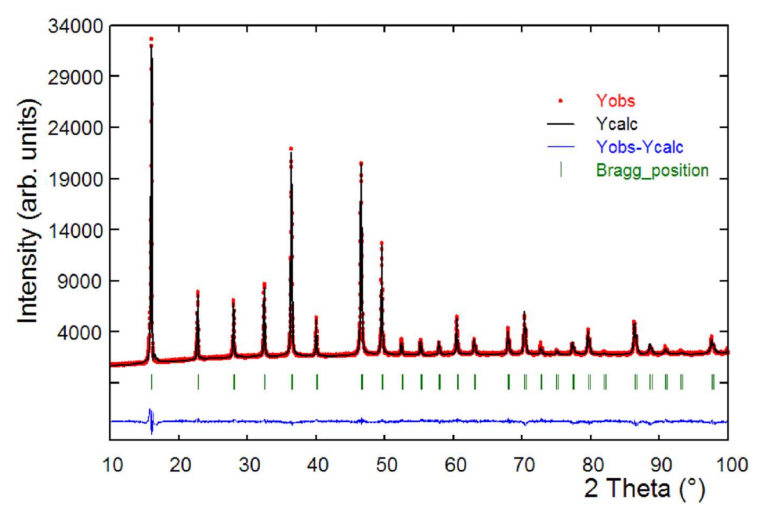

Fig. 1. Final Rietveld plot showing the observed, calculated and difference patterns of $\mathrm{Cu}_{3} \mathrm{TaS}_{4}$.

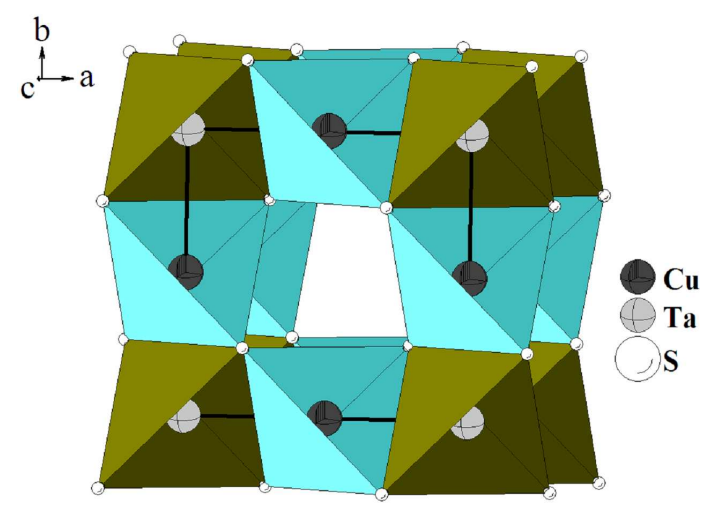

Fig. 2. Unit cell diagram of $\mathrm{Cu}_{3} \mathrm{TaS}_{4}$ show the stacking of the $\mathrm{CuS}_{4}$ and $\mathrm{TaS}_{4}$ tetrahedra.

This ternary compound crystallizes in a sulvanite-type structure, which consists of a three-dimensional arrangement of $\mathrm{CuS}_{4}$ and $\mathrm{TaS}_{4}$ tetrahedra connected by common edges. Figure 2 shows the unit cell diagram of $\mathrm{Cu}_{3} \mathrm{TaS}_{4}$ and the stacking of the tetrahedra which leaves a channel at the centre. The shortest S...S distance in this cavity is $3.900(4) \AA$.

The tetrahedra containing the $\mathrm{Cu}$ cations (mean value $\mathrm{S}-\mathrm{S}$ distances $3.900(4) \AA$ ) are lightly larger than those containing the Ta atoms (mean $\mathrm{S}-\mathrm{S}$ distance is $3.860(4) \AA$ ). All bond angles show minor deviations from the ideal tetrahedral values in a slightly distorted structure. The interatomic distances in the $\mathrm{Cu}_{3} \mathrm{TaS}_{4}$ structure $(2.380 \AA$ and $2.364 \AA)$ are markedly shorter than the sum of their respective ionic radii $(2.940 \AA)$ [23].

A comparison of unit cell parameters and bond distances for the complete family $\mathrm{Cu}_{3}-\mathrm{M}-\mathrm{VI}_{4}$ with $\mathrm{M}=\mathrm{V}$, $\mathrm{Nb}$, Ta and VI = S, Se, Te is shown in Table IV. It is possible to observe that the parameters and the $\mathrm{Cu}-\mathrm{S}$ and $\mathrm{M}-\mathrm{VI}$ distances increase as changing $\mathrm{M}$. This increase can be expected in view of the fact that the ionic radius of $0.36 \AA$ for $\mathrm{V}^{5+}$ cations is greater than that of $0.48 \AA$ for $\mathrm{Nb}^{5+}$ cations, and $0.64 \AA$ for $\mathrm{Ta}^{5+}[23]$. 
X-ray powder diffraction data of $\mathrm{Cu}_{3} \mathrm{TaS}_{4}$.

TABLE I

\begin{tabular}{|c|c|c|c|c|c|c|c|c|}
\hline $2 \theta_{\text {obs }}\left[{ }^{\circ}\right]$ & $d_{\text {obs }}[\AA]$ & $\left(I / I_{0}\right)_{\mathrm{obs}}$ & $h$ & $k$ & $l$ & $2 \theta_{\text {cal }}\left[^{\circ}\right]$ & $d_{\text {cal }}[\AA]$ & $\Delta 2 \theta\left[^{\circ}\right]$ \\
\hline 16.062 & 5.5132 & 100.0 & 1 & 0 & 0 & 16.057 & 5.5149 & -0.005 \\
\hline 22.796 & 3.8976 & 24.2 & 1 & 1 & 0 & 22.784 & 3.8996 & -0.012 \\
\hline 28.005 & 3.1833 & 21.4 & 1 & 1 & 1 & 27.999 & 3.1840 & -0.006 \\
\hline 32.446 & 2.7570 & 26.5 & 2 & 0 & 0 & 32.441 & 2.7575 & -0.005 \\
\hline 36.403 & 2.4659 & 66.9 & 2 & 1 & 0 & 36.396 & 2.4663 & -0.007 \\
\hline 40.015 & 2.2512 & 16.2 & 2 & 1 & 1 & 40.011 & 2.2515 & -0.004 \\
\hline 46.553 & 1.9492 & 63.0 & 2 & 2 & 0 & 46.537 & 1.9498 & -0.016 \\
\hline 49.547 & 1.8382 & 38.6 & 3 & 0 & 0 & 49.543 & 1.8383 & -0.004 \\
\hline 52.424 & 1.7439 & 10.1 & 3 & 1 & 0 & 52.420 & 1.7440 & -0.003 \\
\hline 55.195 & 1.6627 & 9.9 & 3 & 1 & 1 & 55.190 & 1.6628 & -0.005 \\
\hline 57.872 & 1.5920 & 9.0 & 2 & 2 & 2 & 57.870 & 1.5920 & -0.001 \\
\hline 60.475 & 1.5295 & 16.7 & 3 & 2 & 0 & 60.474 & 1.5296 & -0.001 \\
\hline 63.009 & 1.4740 & 10.1 & 3 & 2 & 1 & 63.012 & 1.4739 & 0.003 \\
\hline 67.924 & 1.3788 & 13.3 & 4 & 0 & 0 & 67.927 & 1.3787 & 0.003 \\
\hline 70.319 & 1.3376 & 17.1 & 4 & 1 & 0 & 70.320 & 1.3376 & 0.001 \\
\hline 72.681 & 1.2998 & 8.9 & 3 & 3 & 0 & 72.677 & 1.2999 & -0.004 \\
\hline 75.013 & 1.2651 & 6.8 & 3 & 3 & 1 & 75.005 & 1.2652 & -0.008 \\
\hline 77.305 & 1.2332 & 8.9 & 4 & 2 & 0 & 77.307 & 1.2332 & 0.002 \\
\hline 79.587 & 1.2035 & 13.0 & 4 & 2 & 1 & 79.589 & 1.2035 & 0.001 \\
\hline 81.845 & 1.1759 & 6.2 & 3 & 3 & 2 & 81.854 & 1.1758 & 0.009 \\
\hline 86.343 & 1.1258 & 15.1 & 4 & 2 & 2 & 86.349 & 1.1257 & 0.006 \\
\hline 88.583 & 1.1030 & 7.8 & 4 & 3 & 0 & 88.587 & 1.1030 & 0.004 \\
\hline 90.826 & 1.0815 & 8.2 & 5 & 1 & 0 & 90.822 & 1.0816 & -0.004 \\
\hline 93.051 & 1.0614 & 6.5 & 5 & 1 & 1 & 93.059 & 1.0613 & 0.008 \\
\hline 97.542 & 1.0242 & 10.7 & 5 & 2 & 0 & 97.550 & 1.0241 & 0.008 \\
\hline 99.816 & 1.0068 & 7.1 & 5 & 2 & 1 & 99.812 & 1.0069 & -0.004 \\
\hline
\end{tabular}

Rietveld refinement details for $\mathrm{Cu}_{3} \mathrm{TaS}_{4}$.

TABLE II

\begin{tabular}{l|l|l|l}
\hline \hline molecular formula & $\mathrm{Cu}_{3} \mathrm{TaS}_{4}$ & data range $2 \theta\left[^{\circ}\right]$ & $10-100$ \\
molecular weight $[\mathrm{g} / \mathrm{mol}]$ & 499.9 & step size $2 \theta\left[^{\circ}\right]$ & 0.02 \\
$a[\AA]$ & $6.9670(3)$ & counting time $[\mathrm{s}]$ & 50 \\
$V\left[\AA^{3}\right]$ & $550.6(5)$ & No. step intensities & 4501 \\
$Z$ & 1 & No. independent reflections & 33 \\
space group & $P \overline{4} 3 m(\mathrm{No} .215)$ & peak-shape profile & pseudo-Voigt \\
$D_{\text {calc }}\left[\mathrm{g} / \mathrm{cm}^{-3}\right]$ & 4.95 & $\lambda$ & $\mathrm{Cu} K_{\alpha}(1.54056 \AA)$ \\
$R_{\mathrm{p}}[\%]$ & 4.4 & $R_{\mathrm{wp}}[\%]$ & 6.8 \\
$R_{\exp }[\%]$ & 5.5 & $S$ & 1.2 \\
\hline$R_{\mathrm{p}}=100 \sum\left|y_{\mathrm{obs}}-y_{\mathrm{calc}}\right| / \sum\left|y_{\mathrm{obs}}\right|, \quad S=\left[R_{\mathrm{wp}} / R_{\exp }\right]$, & \\
$R_{\exp }=100\left[(N-P+C) / \sum_{\mathrm{w}}\left(y_{\mathrm{obs}}^{2}\right)\right]^{1 / 2}, \quad N-P+C$ is the number of degrees of freedom, \\
$R_{\mathrm{wp}}=100\left[\sum_{\mathrm{w}}\left|y_{\mathrm{obs}}-y_{\mathrm{calc}}\right|^{2} / \sum_{\mathrm{w}}\left|y_{\mathrm{obs}}\right|^{2}\right]^{1 / 2}$
\end{tabular}

The evolution of the unit cell parameters and unit-cell volume for the sulphide $\mathrm{Cu}_{3}-\mathrm{M}-\mathrm{S}_{4}$ family as function of choice $\mathrm{M}$ element $(x)$ is shown in Fig. 3a. Figure 3b illustrates the variation of the bond distances for the same family. It should be noted that related tendencies are observed in all compounds of the system $\mathrm{Cu}_{3}-\mathrm{M}-\mathrm{VI}_{4}$, sulphides, selenides and tellurides.

Concerning to the solid solution formation, Table $\mathrm{V}$ shows the experimental unit-cell parameters reported for the $\mathrm{Cu}_{3} \mathrm{TaS}_{4-x} \mathrm{Se}_{x}$ system, and Fig. 4 shows that unit- 
TABLE III

Unit cell, atomic coordinates, isotropic temperature factors, bond distances $[\AA]$ and angles $\left[{ }^{\circ}\right]$ for $\mathrm{Cu}_{3} \mathrm{TaS}_{4}$, derived from the Rietveld refinement.

\begin{tabular}{c|c|c|c|c|c|c|c}
\hline \hline Atom & Ox. & Site & $x$ & $Y$ & $z$ & foc & $B\left[\AA^{2}\right]$ \\
\hline $\mathrm{Cu}$ & +1 & $3 \mathrm{~d}$ & $1 / 2$ & 0 & 0 & 1 & $1.2(5)$ \\
$\mathrm{Ta}$ & +5 & $1 \mathrm{a}$ & 0 & 0 & 0 & 1 & $1.2(5)$ \\
$\mathrm{S}$ & -2 & $4 \mathrm{~d}$ & $0.2475(5)$ & $0.2475(5)$ & $0.2475(5)$ & 1 & $1.2(5)$ \\
\hline & & $\mathrm{Cu}-\mathrm{S}$ & $2.380(3) \AA$ & $\mathrm{Ta}-\mathrm{S}$ & $2.364(3) \AA$ & \\
\hline \multicolumn{2}{l}{$\mathrm{S}-\mathrm{Cu}-\mathrm{S}^{(i)}$} & $108.4(1)$ & $\mathrm{S}-\mathrm{Cu}-\mathrm{S}^{(i i)}$ & $110.0(1)$ & $\mathrm{S}-\mathrm{Cu}-\mathrm{S}^{(i i i)}$ & $110.0(1)$ \\
$\mathrm{S}^{(i)}-\mathrm{Cu}-\mathrm{S}^{(i i)}$ & $110.0(1)$ & $\mathrm{S}^{(i)}-\mathrm{Cu}-\mathrm{S}^{(i i i)}$ & $109.3(1)$ & $\mathrm{S}^{(i i)}-\mathrm{Cu}-\mathrm{S}^{(i i i)}$ & $108.4(1)$ \\
$\mathrm{S}^{(i v)}-\mathrm{Ta}-\mathrm{S}^{(v)}$ & $109.5(1)$ & $\mathrm{S}^{(i v)}-\mathrm{Ta}-\mathrm{S}^{(i)}$ & $109.5(1)$ & $\mathrm{S}^{(i v)}-\mathrm{Ta}-\mathrm{S}$ & $109.5(1)$ \\
$\mathrm{S}^{(v)}-\mathrm{Ta}-\mathrm{S}^{(i)}$ & $109.5(1)$ & $\mathrm{S}^{(v)}-\mathrm{Ta}-\mathrm{S}$ & $109.5(1)$ & $\mathrm{S}^{(i)}-\mathrm{Ta}-\mathrm{S}$ & $109.5(1)$ \\
\hline
\end{tabular}

Symmetry codes: (i) $y,-x,-z ;(i i) 1-x,-y, z ;(i i i) 1-y, x,-z ;(i v)-y, x,-z ;(v)-x,-y, z$

TABLE IV

Comparative table of the $\mathrm{Cu}_{3}-\mathrm{M}-\mathrm{VI}_{4}(\mathrm{M}=\mathrm{V}, \mathrm{Nb}, \mathrm{Ta}, \mathrm{VI}=\mathrm{S}$, Se, Te) sulvanite compounds $([*]=$ this work $)$.

\begin{tabular}{l|c|c|c|c|c}
\hline \hline & $a[\AA]$ & $V\left[\AA^{3}\right]$ & $\mathrm{Cu}-\mathrm{VI}[\AA]$ & M-VI $[\AA]$ & Ref. \\
\hline $\mathrm{Cu}_{3} \mathrm{VS}_{4}$ & $5.393(1)$ & $156.85(5)$ & $2.299(1)$ & $2.219(1)$ & 9 \\
$\mathrm{Cu}_{3} \mathrm{NbS}_{4}$ & $5.5001(6)$ & $166.38(3)$ & $2.359(1)$ & $2.311(1)$ & 10 \\
$\mathrm{Cu}_{3} \mathrm{TaS}_{4}$ & $5.5145(1)$ & $167.70(1)$ & $2.380(3)$ & $2.364(3)$ & {$\left[{ }^{*}\right]$} \\
$\mathrm{Cu}_{3} \mathrm{VSe}_{4}$ & $5.5636(5)$ & $172.21(3)$ & $2.392(1)$ & $2.357(1)$ & 11 \\
$\mathrm{Cu}_{3} \mathrm{NbSe}_{4}$ & $5.638(1)$ & $179.22(6)$ & $2.442(1)$ & $2.443(1)$ & 12 \\
$\mathrm{Cu}_{3} \mathrm{TaSe}_{4}$ & $5.6600(1)$ & $181.32(1)$ & $2.454(3)$ & $2.461(3)$ & 13 \\
$\mathrm{Cu}_{3} \mathrm{VTe}_{4}$ & - & - & - & - & - \\
$\mathrm{Cu}_{3} \mathrm{NbTe}_{4}$ & $5.9217(1)$ & $205.65(1)$ & $2.588(4)$ & $2.633(4)$ & 14 \\
$\mathrm{Cu}_{3} \mathrm{TaTe}_{4}$ & $5.930(2)$ & $208.5(1)$ & $2.596(1)$ & $2.650(1)$ & 15
\end{tabular}

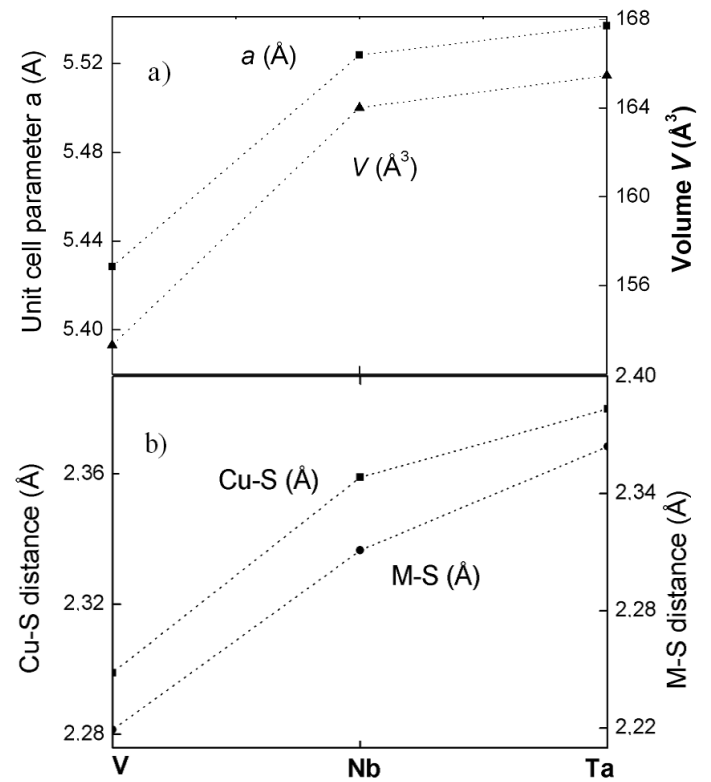

Fig. 3. Bond distances $\mathrm{Cu}-\mathrm{S}$ and $\mathrm{M}-\mathrm{S}$ as function of the Mn cation (V, Nb, Ta). The dotted lines represent a linear fit. (a) Unit cell parameter $a(\AA)$ and cell volume $\left(\AA^{3}\right)$, and (b) bond distances $\mathrm{Cu}-\mathrm{S}(\AA)$ and $\mathrm{M}-\mathrm{S}(\AA)$, as function of the $\mathrm{M}$ cation $(\mathrm{V}, \mathrm{Nb}, \mathrm{Ta})$ for the sulfide $\mathrm{Cu}_{3} \mathrm{MS}_{4}$ system.

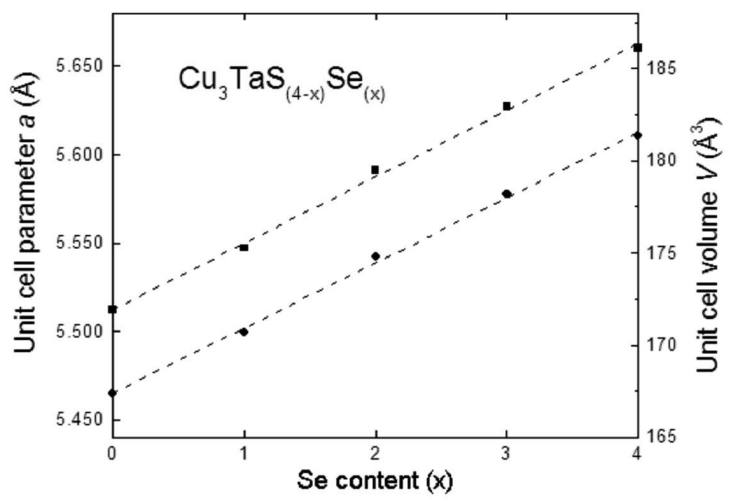

Fig. 4. Unit cell parameter $a(\AA)$ and cell volume $\left(\AA^{3}\right)$ for the $\mathrm{Cu}_{3} \mathrm{TaS}_{4-x} \mathrm{Se}_{x}$ system. The dotted lines represent a linear fit.

-cell parameters and unit-cell volume increase linearly with increasing Se content which suggests for this system a solid solution formation in all range of compositions. Since all the compounds of the system $\mathrm{Cu}_{3}-\mathrm{M}-\mathrm{VI}_{4}$ are isostructural, solid solutions in all combinations are expected. 
TABLE V

Unit cell parameters vs. composition for the system $\mathrm{Cu}_{3} \mathrm{TaS}_{4-x} \mathrm{Se}_{x}$ system ([*] = this work).

\begin{tabular}{l|l|c|c|c}
\hline \hline & & $a[\AA]$ & $V\left[\AA^{3}\right]$ & Ref. \\
\hline$x=0$ & $\mathrm{Cu}_{3} \mathrm{TaS}_{4}$ & $5.5145(1)$ & $167.70(1)$ & {$[*]$} \\
$x=1$ & $\mathrm{Cu}_{3} \mathrm{TaS}_{3} \mathrm{Se}$ & 5.547 & 170.7 & 4 \\
$x=2$ & $\mathrm{Cu}_{3} \mathrm{TaS}_{2} \mathrm{Se}_{2}$ & 5.591 & 174.8 & 4 \\
$x=3$ & $\mathrm{Cu}_{3} \mathrm{TaSSe}_{3}$ & 5.627 & 178.2 & 4 \\
$x=4$ & $\mathrm{Cu}_{3} \mathrm{TaSe}_{4}$ & $5.6600(1)$ & $181.32(1)$ & 13
\end{tabular}

\section{Conclusions}

The crystal structure of the ternary $\mathrm{Cu}_{3} \mathrm{TaS}_{4}$ was refined by the Rietveld method using X-ray powder diffraction data. This compound is isostructural with the mineral sulvanite. For the complete system $\mathrm{Cu}_{3}-\mathrm{M}-\mathrm{VI}_{4}$ with $\mathrm{M}=\mathrm{V}, \mathrm{Nb}, \mathrm{Ta}$ and $\mathrm{VI}=\mathrm{S}, \mathrm{Se}, \mathrm{Te}$, solid solutions are expected.

\section{Acknowledgments}

This work was supported by CDCHT-ULA and FONACIT (grant LAB-97000821).

\section{References}

[1] M.L. Doublet, S. Remy, F. Lemoigno, J. Chem. Phys. 113, 5879 (2000).

[2] N. Shannon, R. Joynt, Solid State Commun. 115, 411 (2000).

[3] K.H. Schmidt, A. Müller, J. Bouwma, F. Jellinek, J. Mol. Struct. 11, 275 (1972).

[4] A. Mueller, W. Seivert, Z. Anorg. Allg. Chem. 406, 80 (1974).

[5] D. Petritis, G. Martinez, C. Levy-Clement, O. Gorochov, Phys. Rev. B 23, 6773 (1981).
[6] W. Espinosa García, A. Morales Aramburo, J.M. Osorio Guillen, Rev. Colomb. Fis. 40, 36 (2008).

[7] P.F. Newhouse, P.A. Hersh, A. Zakutayev, A. Richerd, H.A.S. Platt, D.A. Keszler, J. Tate, Thin Solid Films 517, 2473 (2009).

[8] L. Pauling, R. Hultgren, Z. Kristallogr. 84, 204 (1932).

[9] C. Mujica, G. Carvajal, J. Llanos, O. Wittke, Z. Kristallogr. New Cryst. Struct. 213, 12 (1998).

[10] M. Kars, A. Rebbah, H. Rebbah, Acta Crystallogr. E 61, I180 (2005).

[11] K.O. Klepp, D. Gurtner, Z. Krystallogr. New Cryst. Struct. 215, 4 (2004).

[12] Y.J. Lu, J.A. Ibers, J. Solid State Chem. 107, 58 (1993).

[13] G.E. Delgado, A.J. Mora, S. Durán, M. Muñoz, P. Grima-Gallardo, J. Alloys Comp. 439, 346 (2007).

[14] G.E. Delgado, A.J. Mora, P. Grima-Gallardo, S. Durán, M. Muñoz, M. Quintero, Chalc. Lett. 6, 335 (2009).

[15] J. Li, H.-Y. Guo, D.M. Proserpio, A. Sironi, J. Solid State Chem. 117, 247 (1995).

[16] ICSD-Inorganic Crystal Structure Database, Set 08-1, Gmelin Institute, Kalrsruhe, Germany 2008.

[17] A. Boultif, D. Louër, J. Appl. Crystallogr. 37, 724 (2004).

[18] A.D. Mighell, C.R. Hubbard, J.K. Stalick, National Bureau of Standards, Tech. Note 1141 (1981).

[19] P.M. de Wolff, J. Appl. Crystallogr. 1, 108 (1968).

[20] G.S. Smith, R.L. Snyder, J. Appl. Crystallogr. 12, 60 (1979).

[21] H.M. Rietveld, J. Appl. Crystallogr. 2, 65 (1969).

[22] J. Rodriguez-Carvajal, Fullprof, version 5.0, ILL, CEA-CNRS, France 2011.

[23] S.D. Shannon, Acta Crystallogr. A 32, 751 (1976). 